\title{
Research on the Application of the Non-directive Teaching in College Oral English Instruction in Micro-media Context
}

\author{
ZHAO Ji-tao \\ Chongqing University of Posts and Telecommunications, Chongqing, China
}

\begin{abstract}
With the continuous Promotion of the Belt and Road Initiative in China, the requirements for oral English competence of college graduates have been becoming increasingly important. However, the oral English instruction of many colleges still lacks interaction and most students have few opportunities to speak English in class. In order to enhance the effectiveness of English teaching, this paper aims to introduce Non-directive Teaching Theory of Rogers, an American humanistic psychologist, and micro-media environment and create a better dynamic and interactive classroom atmosphere and authentic environment to speak English through group discussion, English debate, and situation learning and so on.
\end{abstract}

Keywords: Non-directive Teaching Theory, college oral English, application

\section{Introduction}

Many English learners in China only lay emphasis on the passing of examinations instead of regarding English as a tool for communication. It is truly that most college students lack the communicative competence. A variety of teaching methods is constantly emerging, to a great extent, which promoted the development of college oral English teaching. However, these reforms mainly emphasize the forms of teaching instead of involving the essence of the issue, that is, either student-centered teaching form or teacher-centered teaching form. Hence, the Non-directive Teaching Theory, an effective student-centered teaching theory, should be introduced into college oral English instruction, which could cultivate the competence for self-study and communication. Non-directive Teaching Theory, also known as humanistic teaching theory, was put forward by an American humanistic psychologist, Carl Rogers who was an American humanistic psychologist in the 1960s in the United States. Non-directive teaching does not mean a teaching theory without guidance, while it means an artistic teaching without direct command. Rogers subscribed to the learner at the center, the emphasis on the emotional elements, the equal partner relationship between teacher and students, the open atmosphere in non-directive teaching and self-evaluation by students. The basic goal is to help students achieve greater integration of themselves. The teacher's teaching goal is to create a kind of learning context so as to facilitate the inspiring, assessment, and evaluation of various new perception processes, which could help students understand their own needs and value.

Fund Project: Social Science Fund Project of Chongqing University of Posts and Telecommunications (2018): Research on College English Academic Counseling Path Innovation From Micro-media Perspective (K2018-49).

ZHAO Ji-tao, Master of Education, School of Foreign Languages, Chongqing University of Posts and Telecommunications, Chongqing, China. 
Sun Yi and Jing Guoping (2018) illustrate the status quo of pupils' autonomous learning in primary school and explore the strategies to enhance autonomous learning within Non-directive Teaching Theory. Nevertheless, most studies in the application of Non-directive Teaching Theory exist in the traditional atmosphere instead of the brand new micro-media context, which could be regarded as the WeChat Subscription, WeChat small programs, and other learning ways of apps. By way of micro-media, the learners could be allowed to accept the micro-content in anywhere and anytime.

In this paper, Non-directive Teaching Theory was applied to college oral English instruction in order to find a better approach to promote the oral English competence of college students.

\section{The Analysis of the Present Oral English Instruction in China}

This part analyzes problems from the points of view between the colleges and the college students, which depicts the status quo of oral English instruction in China.

\section{The Objective Problem From the Colleges' Point of View}

The status of college oral English instruction. Although English teaching paid attention to enlightening students to speak English, it mainly aims to make students analyze and understand the text content, instead of cultivating students' oral English ability.

The lack of the necessary linguistic context. As a part of English teaching, oral English instruction should face the broad aspects and adopt various flexible teaching methods. The current approaches of oral English instruction in the classroom limits the way of the conventional classroom questions and answers, mainly concentrating on a small group of top students. Most students have little opportunities of oral English exercise. Lacking necessary linguistic environment, the students had few chances to listen to and speak English, which directly leads to less English training practice.

\section{The Subjective Problem From the College Students' Point of View}

The lack of confidence and afraid of being teased. Many students have little confidence in their ability to speak and are afraid of being teased by others. They often feel unease, which often reinforced by students' anxiety to speak well and some teachers' error treatment techniques. Teachers need to provide better contexts for students to develop oral English skills and use these skills in active learning roles in the classroom.

The influence of assessment system. Since the lack of oral English examinations for enrollment before, most students only emphasize the remarks of the English test and they did not regard oral English as an important matter. Some students are forced to put themselves to the endless exercises under the high pressure of entrance examination. They just do some school assignments in written forms and lack of enthusiasm for English learning. Thus it causes the situation that students cannot speak English fluently even though they have learned English for many years. Oral English instruction went the other way comparing with English quality-oriented education.

\section{Applying Non-directive Teaching Into College Oral English Instruction in Micro-media Context}

Non-directive Teaching Theory is a kind of student-centered teaching theory, which has a great significance in college oral English instruction. But in the process of application, we need to use Non-directive Teaching Theory flexibly and properly with the assistance of micro-media. Then, let's take some specific cases as example: 
In the process of teaching, teachers can attempt to encourage students to learn by themselves through some useful and beneficial WeChat official account after class, and meanwhile, apply the small programs on WeChat into the classroom teaching. Similarly these applications can be used in the self-assessment and mutual assessment. Therefore, non-directive teaching method can absolutely been applied into college oral English teaching in mini-media environment.

\section{Shifting the Roles and Regarding the Students as Persons With Tremendous Potential}

Humans has gift to learn. Their brains almost consist of unlimited potential. So the teachers should change their own roles from masters to facilitators.

Taking students' interests into full consideration. To enhance the students' learning interests in English, Confucius, the ancient Chinese educationalist, once said that people who knew it better than who worked on it, who worked on it not as good as who loved it, which manifests the importance of interests. Teaching could use the diverse methods of creating English context, role-play, group conversation, stories, singing songs, besides, curricular activities and abundant colorful extracurricular exercise, which gave students the opportunities and new stimulus to express themselves. In addition, the class should often held some extra-curricular activities, such as English sitcoms, the English poetry or article recitation, the English songs contest, and so on.

According With the students' Zone of Proximal Development. College oral English instruction should be implemented step by step according to students' true proficiency and skills. Vygotsky defined Zone of Proximal Development (ZPD) as the distance between the actual developmental level as determined by independent problem solving and the level of potential development as determined through problem solving under adult guidance or in collaboration with more capable peers. Whether in content or form, the teacher should use the micro-media to organize the oral English activities and training based on the students' authentic English competence. If students feel it too difficult to accept, they'll lose confidence. In the same way, they'll lose their learning interests if the English material is too easy.

\section{Building Open Classroom Atmosphere}

Another effective interaction appears among students. In this kind of interaction, the teacher is just a facilitator and the students are the main participants.

The method of the English debate. Debate is a communication process in which participants argue for and against a given topic. There are many kinds of debate. For example, the teacher give an open topic for students to debate, and students are trying to make a future plan. Do they want to go to a graduate school or to find a job in a company? Students are required to consider advantages and disadvantages over these two future plans. Debate is a heated form in the grouping interaction. The teacher formulates a topic for the students to express their own opinions using the learned language knowledge as strengthen the students' reflection in the argument.

The approach of group discussion. One of the efficient and favorite student-student patterns is group discussion. This allows students to work together in groups helping one another to achieve the expected goals. Cooperative group work is a popular way of working in language classes to allow learners to communicate with each other and be engaged into the process of learning. Usually a class is divided into pairs or groups with four or five members, and all the groups discuss a topic or work on a task with their group members at the same time, and the teacher is only a participant. Group discussion has a number of advantages, which can reduce the dominance 
of the teacher over the class, instead of involving the students participation, increase their personal opportunities to practice, and give them more active roles in learning.

\section{Creating Authentic English Teaching Situation}

The ultimate goal of situated teaching is to develop the learning interest of students and encourage students to make the most of English proactively. With the assistance of new media, shy students become more outgoing and aggressive students become more sensitive and moderate.

The approach of situational teaching. Teachers ought to apply a various of approaches of situational teaching, for students may immerse in the authentic environment. Role-playing is a form used in situational teaching approach to arouse the learners' curiosity. Guessing is another form of the situational teaching approach. Guessing in communicative activities takes an active effect to encourage the students to acquaint the second language in the relaxing environment; for example, one student expresses the meaning of the word while the other guesses what the word is.

The approach of extra-curriculum: English Salon or English Corner. Except oral English instruction in the class, the teacher also should create the extra-curriculum out of class, such as English Salon or English Corner. English Salon or English Corner is really a good place for English lovers. It provides excellent conditions and opportunities. In many famous universities, there are English corners in the evening. And we can see different people there, such as foreign teachers, foreign companies staff who speak fluent English, overseas returnees, and college students in school.

\section{Giving the Right of Assessment to Students}

The improvement of students' spoken English ability is a continuous and ongoing academic development, so the Non-directive Teaching Theory holds the view that students should own the right to assess themselves. Self-assessment by students themselves is the most desirable method of assessment in student-centered curriculum, and students who have experienced a self-assessment will certainly have more opportunities for growth. Thus, we may use an application to give self-assessment and peer-assessment.

Self-assessment. Self-assessment means that you can judge the quality of your own work and how much progress you have made. Students are required to assess their own performance in oral class activities. Self-assessment can be carried out both in and out of the class. And self-assessment can also be carried out at any time and through different approaches. The teacher draws up a list of several assessment items and standards, such as learning motivation, fluency, pronunciation, and intonation, then students can choose among them to assess their own performance. It's worth noting that students draw up the assessment items and standards, and assess their own performance, and this kind of self-assessment should be conducted under the guidance of teachers. Self-assessment makes students privately but directly face personal attitudes and biases that may unconsciously cause barriers to learning. Its purpose is to promote internal reflection, with providing paradigms, biases, or learning barriers to the surface level.

Peer-assessment. In case of the ignorance of students' weakness in self-assessment process, the teacher also should adopt their assessment method of peer-assessment. Students may feel more relaxed about sharing their problems, and receiving feedback from peers in conditions which do not make them feel exposed or threatened. Especially in the group activities, while the students cooperate with each other to finish the tasks, they 
assess their group member's performance according to the scoring criteria as well. Feedback was given promptly. After the assessment, students were informed how they had performed immediately. This process enables them to learn from each other.

\section{Conclusion}

Non-directive teaching in micro-media context has changed the traditional teaching mode. These internships and the real environment may well provide students with more opportunities to practice and apply oral English quite often. Although leading us into a brand new era, the use of non-directive teaching in college oral English and what effects it will cause in the end will take time to test. It's necessary to consider teaching syllabus, students' learning attitudes, and teachers' level, then further give the feedback through this mode. Only the integration of constant testing, responses and feedback, summing up and assessment, the ultimate goals of college oral English instruction can be better achieved.

\section{References}

Ellis, R. (1994). The study of second language acquisition. New York: Oxford University Press.

Joyce, B., Weil, M., \& Calhoun, E. (2004). Non-directive teaching—the learner at the center/models of teaching. Beijing: China Light Industry Press.

Macmillan English dictionary for advanced learners. (2017). Beijing: Foreign Language Teaching and Research Press.

Tenenbaum, S. (1959). Carl R. Rogers and non-directive teaching. Educational Leadership, 16(5), 296-302, 328.

Vygotsky, L. (1960). The development of senior psychological function. Russian Academy of Educational Sciences Press 罗杰斯. (1984). 治疗和教育中的有意义的学习. 全球教育展望, (2), 29-37.

孙艺, 靖国平. (2018). 以非指导性教学思想促进小学生自主学习的策略. 教育导刊, (8), 60-64.

薛丰年. (2016). 微媒体视域下的大学英语教学. 教育理论与实践, (6), 55-56.

易丹妮, 徐清源. (2019). “微时代”大学生思想政治教育工作研究. 课程教育研究, (3), 94-95.

赵佳寅. (2017). 大学生思想政治“微教育”模式研究. Changchun: 吉林大学.

朱纯. (1994). 外语教学心理学. Shanghai: 上海外语教育出版社. 